\title{
Satisfaction of Filipino Crop Farmers on Agricultural Credit
}

\author{
Genalyn P. Lualhati ${ }^{1}$, Gemma V. Manalo ${ }^{2}$, Jaypee M. Manalo² \& Jinefer A. Ramos ${ }^{2}$ \\ ${ }^{1}$ College of Teacher Education, Batangas State University JPLPC-Malvar, Philippines \\ ${ }^{2}$ College of Accountancy, Business, Economics and International Hospitality Management, Batangas State \\ University JPLPC-Malvar, Philippines \\ Correspondence: Genalyn P. Lualhati, College of Teacher Education, Batangas State University JPLPC-Malvar, \\ Batangas Province, 4232, Philippines. E-mail: genpanganiban_0301@yahoo.com
}

Received: July 11, 2018; Accepted: September 9, 2018; Published: September 12, 2018

\begin{abstract}
Agricultural credit is an important part of the broader Agribusiness, which is encompassing farming and farmingrelated commercial activities. Hence, the study determined the level of satisfaction of crop farmers on agricultural credit in two barangays San Juan and San Andres, Malvar, Batangas, with an end goal of enhancing agricultural credit management. Through descriptive method of research, the study revealed that majority of the farmers used to plant rice with a land area of $0.5-1.0$ hectare that avail agricultural credit 2 to 3 times a year. Further, the level of satisfaction of crop farmers on agricultural credit along with documents/requirement, penalties and charges, interest rates, credit terms and conditions and repayment scheme are dissatisfied. This study offered recommendations, if properly implemented and actualized by concerned authorities, may ensure sustainable and accessible rural credit facilitation.
\end{abstract}

Keywords: agriculture, credit, satisfaction, farmers, finance

\section{Introduction}

Agriculture plays a vital role in a country, like Philippines, because this department contribute a lot in the development of the economy.Annual documentation of the agriculture growth and the challenges in farming is important so as to plan and organize programs for the small farmers. These has been the concerns of the Department of Agriculture (DA), hence; part of their annual planning is the determination of the growth of agriculture in each region. In fact, the SEPO Policy Brief (2009) revealed that the Central Luzon is ranked first and has the largest share.

In Region IV-A, Batangas has its largest percentage share of regional income from agriculture sector which from among the industries constitutes the highest contribution in terms of production value, employment and income. Batangas economy in terms of income is highest in service sector with $50.92 \%$, agriculture with $32.49 \%$ and industry with $17.09 \%$. The economic based industries where the province is relatively efficient are the Agritourism Enterprises development. The positive association of agriculture sector shows that province is a major supplier of agriculture products beyond its geographical boundaries particularly in National Capital Region (NCR).

One of the municipalities in Batangas which focuses on planting rice, corn and vegetables is Malvar. The Municipality of Malvar is located in the northeastern part of the province of Batangas, bounded in the north by the City of Tanauan on the east by the Municipality of Sto. Tomas, on the south by the City of Lipa, and on the west by the Municipality of Balete. According to the latest census, Malvar has a total population of 45,952 and a total of 9,777 numbers of households. It has a total land area of 3,759 hectares and its major economic activities consist mainly of agriculture, commerce, services and industry.

Therefore, the small town of Malvar is occupied by people that fall into low or middle socio-economic status. As a rural area, it has been observed for the past years that majority of the people are dependent on agriculture and agriculture-related industries for their jobs and incomes to support their living. However, finance has been the evident issue of the farmers in Malvar. This is supported by the findings of the DA that small farmers continue to find it difficult to access formal credit and financing despite government efforts to increase the flow of credit to the rural sector. Only a small portion of the lending portfolio of commercial banks goes to agriculture, arising from climatic shocks, diseases and infestations, means that small farmers are generally considered by banks and formal institutions to be non-creditworthy. There are also cases that small farmers are having a hard time to meet the 
requirements and processes needed to have an access to formal financing, which makes them avail to informal credit sources. (SEPO, Policy Brief, 2009)

In the year 1997, the Agriculture and Fisheries Modernization Act (AFMA) was passed by the Senate. The AFMA is a comprehensive blueprint for agriculture modernization and rural development. This aims to transform the rural economy through the introduction of modern technology, increasing availability of rural financing, increasing investments in agricultural infrastructure, improving the links between farmers and markets, both domestic and international, and others. Though this law, it is believed that this will be the answer to the country's agricultural crisis.

Many years had passed after the passage of the law, yet, the agriculture sector has been performing below expectations and potential most especially in the rural areas as revealed by the Senate Economic Planning Office (SEPO) Policy Brief.Small farmers in the rural areas are experiencing adversities and it is charged to the minimal sources of fund to enrich their land and crops. This could be attributed to the fact that more funds are allotted for purchasing of goods and services instead of credit programs for the farmers. According to David (2007), large share of the agriculture spending goes to financing grains trading, provision of seeds and planting materials, all of which are essentially private goods and services. With this, public expenditures tend to favour private agencies over credit programs. This scenario forces the farmers to think of other means to achieve their starting capital. Seeking help from different formal and non-formal sources of credit has been the usual practice of the farmers in rural areas to sustain their needs.

Credit programs give starting capital which results to more crops planted and high income. Similarly, it ensures to lessen poverty of the people who relies entirely for planting as source of living. It can also increase business skills of small farmers in terms of budgeting and profit management. In this light, their satisfaction in the availment is a good thing to take into account. Satisfaction on the formal credit sources will give the farmers courage to avail repeatedly and to lessen the availment from non-formal sources. As cited by Armstrong et al. (2003), satisfaction depends upon the observed performance of a company or any institutions to meet the borrower's expectations. If the performance falls short of the customer expectation, the buyer is dissatisfied and will no longer avail the service.

With a felt need to increase the amount of financing funds to the rural sector as well as further improving accessibilityand availability of these funds to small farmers, the researchers found it deemed necessary to make a study that will determine the satisfaction of crop farmers on agricultural credit in terms of documents/requirements, penalties and charges, interest rates, credit terms and condition, and repayment scheme in the two barangays in Malvar, Batangas.

Through the conduct of this study, the investigators, may have baseline idea on what could be the additional financial supports that can be extended to the farmers in order to sustain their farms and promote agricultural development in the locality. The result of the study could be an answer to the pressing need of sustainable and accessible rural credit facilitation.

\subsection{Objectives of the Study}

This investigation determined the level of satisfaction of crop farmers on agricultural credit in two barangays such as San Juan and San Andres, Malvar, Batangas, with an end goal of formulating the implications of the findings to rural credit facilitation. Specifically, it sought to answer the following questions: What is the profile of the crop farmers in terms of crops planted, land area; and frequency of availment?; How does the satisfaction of the crop farmers on agricultural credit may be described along with documents/requirement, penalties and charges, interest rates, credit terms and conditions, and repayment scheme? Lastly,is there significant difference on the satisfaction of crop farmers when grouped according to their profile?

\section{Methodology}

The researchers made used of a descriptive method using the self-made questionnaire. Further, they did not use any sampling technique for they intend to get data from the 117 farmers of the two barangays in Malvar such as San Juan and San Andres. The researchers believed that greater number would give them extensive data that could give them more facts to analyse and evaluate the problems posted in this study.

Previous researches, articles publish in the net, and other reading materials served as references for the researchers to be able to gather related information about the study. The researchers also went to different public and private libraries. In quantifying the descriptive response of the respondents on their satisfaction, this study made use of the four-point scale where four is the highest and one as the lowest. This follows the Likert-type scale; it was applied to measure the evaluation of the respondents on the items raised in the study. These are presented in terms of weighted means with their corresponding descriptive equivalents. 


\begin{tabular}{lll}
\hline Numerical Rating Value & Scale Range & Verbal Interpretation \\
\hline 4 & $3.25-4.00$ & Highly Satisfied \\
3 & $2.50-3.24$ & Satisfied \\
2 & $1.75-2.49$ & Least Satisfied \\
1 & $1.00-1.74$ & Not Satisfied \\
\hline
\end{tabular}

The quantitative data gathered were subjected for checking, scoring, analysis and interpretation with the help of the statistician. The researchers with the help of the statistician made a careful evaluation of the results of the questionnaires. Each item in the questionnaire was analysed and interpreted to come up with some implication of the findings to rural credit facilitation.

\section{Results and Discussions}

This chapter covers the presentation, analysis and interpretation of the quantitative data gathered in the investigation. The discussions of the findings are patterned in a manner that coincides with the organization of the problems posed in the study.

\subsection{Profile of the Respondents}

The succeeding tables present the profile of the respondents in Malvar Batangas. This was grouped according to crops planted, land area and frequency of availment.

Table 1. Profile of the Crop Farmers

\begin{tabular}{lll}
\hline Profile & Frequency & Percentage \\
\hline Crop Planted & 26 & 22.20 \\
Vegetable & 46 & 39.30 \\
Rice & 45 & 38.50 \\
Corn & $\mathbf{1 1 7}$ & $\mathbf{1 0 0 . 0 0}$ \\
\hline TOTAL & 15 & 12.80 \\
\hline Land Area & 59 & 50.40 \\
Less than 0.5 hectare & 43 & 36.80 \\
0.5 hectares - 1.0 hectare & 5 Mre than 1.0 hectares & 43 \\
\hline TOTAL & $\mathbf{1 1 7}$ & $\mathbf{1 0 0 . 0 0}$ \\
\hline Frequency of Availment & 1 & 0.85 \\
6 or more times a year & 2 & 1.71 \\
4-5 times a year & 2 & 58.12 \\
2-3 times a year & 68 & 39.32 \\
\hline Once in a year & 46 & $\mathbf{1 0 0 . 0 0}$ \\
\hline TOTAL & $\mathbf{1 1 7}$ & \\
\hline
\end{tabular}

Majority of the farmers used to plant rice having a percentage of 39.30 which is equivalent to 46 respondents, with a land area of $0.5-1.0$ hectares which is equivalent to 59 or 50.40 percent of the population that 68 of the respondents or 58.12 percent of them availed agricultural credit 2 to 3 times a year.

Rice or locally known as palay, bigas, kanin, is common to the Filipinos. According to the Department of Agriculture (DA), as rice is a food staple, it is an economic commodity. It is both a major expenditure item and a source of income for many households. The demand for this crop in the country crosses all social classes, with a percentage of rural households depending upon the various stages of rice production as livelihood.

Further, according to the study of Abelido (2006), the farmer beneficiaries use the borrowed amount for traditional functions or for personal obligation than for agricultural productivity, the more they need it for agricultural, but supervised credit so that the goals of the credit assistance program could be met and the beneficiaries' family and community could prosper. 


\subsection{Satisfaction of the Respondents on Agricultural Credit}

The succeeding tables present the data gathered through the questionnaire accomplished by the respondents. The data presented herein concern on the satisfaction of crop farmers on agricultural credit according to requirements/ documents, penalties and charges, interest rates, credit terms and conditions and repayment scheme.

Table 2. Requirements/ Documents

\begin{tabular}{lll}
\hline Statements & Mean & Interpretation \\
\hline I am satisfied on agricultural credit as to therequired documents because & & \\
the bank... & & \\
1. requires minimal number of documents on loan application. & 1.89 & Disagree \\
2. imposes clear processing of requirements. & 2.51 & Agree \\
3. provides comprehensive agreement policies & 2.49 & Disagree \\
(e.i. identifying loans, interest rate and maturity date). & & \\
4. provides easy process of security agreement. & 2.36 & Disagree \\
5. requires collateral documents that are easy to provide. & 2.21 & Disagree \\
\hline Composite Mean & $\mathbf{2 . 2 9}$ & Dissatisfied \\
\hline
\end{tabular}

The assessment of the farmers on documents and requirements is dissatisfied as revealed by the obtained composite mean which is 2.29. This means that the respondents are not satisfied in availing credit in formal sources in terms of documents and requirements. Banks were very strict with the necessary documents and requirements.

As supported by the study of Tulagan et al. (2013), in their findings that the loan assistance extended for agricultural production in the municipality is not enough to be able to meet the financial needs of the farmers because of too small portion of fund allotted to it. Also, acquiring such loans is not easy because of many requirements needed for them to be able to avail it.

Table 3. Penalties and Charges

\begin{tabular}{lll}
\hline Statement & Mean & Interpretation \\
\hline $\begin{array}{l}\text { I am satisfied on agricultural credit in terms of penalties and } \\
\text { charges because... }\end{array}$ & \\
$\begin{array}{ll}\text { 1. of low amount of late payment fee incurred. } \\
\text { 2. it provides me opportunity to settle first the principal amount }\end{array}$ & 2.05 & Disagree \\
before the interest. & 2.29 & Disagree \\
3. the bank imposes low service charge. & 2.49 & Disagree \\
$4 . \quad$ there is no service and transaction fees incurred. & 2.36 & Disagree \\
$5 . \quad$ the bank provides me a clear copy of the charges incurred & 2.35 & Disagree \\
before its due date. & & \\
Composite Mean & $\mathbf{2 . 3 1}$ & Dissatisfied \\
\hline
\end{tabular}

The satisfaction of crop farmers on agricultural credit in terms of penalties and charges has a composite mean of 2.31 with the verbal interpretation of dissatisfied. This result indicates that respondents cannot afford the charges imposes by the bank when they can't pay the loan on time. As supported by Albert (2013), the banks should collect charges only for services, which have been notified and agreed upon by their customers, and should provide information a month in advance about the proposed changes in service charges. They should also inform customers in an appropriate manner about recovery of charges from an account or transaction. They may also have to inform the customers in all cases when a transaction initiated itself results in or is likely to lead to a shortfall in the minimum balance required to be maintained. 
Table 3. Interest Rates

\begin{tabular}{lll}
\hline Statement & Mean & Interpretation \\
\hline I am satisfied on agricultural credit in terms of its interest & & \\
rates because... & & \\
1. it is lower than what I am expected. & 1.70 & Strongly Disagree \\
2. it is based on legal interest. & 1.76 & Disagree \\
3. it is agreed by both parties. & 1.98 & Disagree \\
4. it can be paid annually. & 1.93 & Disagree \\
5.it is on instalment basis. & 1.97 & Disagree \\
\hline Composite Mean & $\mathbf{1 . 8 7}$ & Dissatisfied \\
\hline
\end{tabular}

Table 4. Credit terms and Conditions

\begin{tabular}{lll}
\hline Statement & Mean & Interpretation \\
\hline $\begin{array}{l}\text { I am satisfied on agricultural credit in terms of its credit } \\
\text { terms and conditions because... }\end{array}$ & \\
1. its payment scheme is on installment basis. & 2.14 & Disagree \\
2. of its low interest rates. & 1.99 & Disagree \\
3. it does not charge late payment. & 2.26 & Disagree \\
4. its mode of payment is very convenient. & 2.15 & Disagree \\
5. it offers discount on early payment. & 2.01 & Disagree \\
\hline Composite Mean & $\mathbf{2 . 1 1}$ & Dissatisfied \\
\hline
\end{tabular}

Generally, the assessment of the farmers on credit terms and condition is dissatisfied which was evident in its composite mean of 2.11. This indicates that banks want to assure that the borrowers will follow on their restrictions. Besley et al. (2012) said that the most important aspect of the terms of credit deals with the payment arrangements. Firms need to determine when the credit period will begin, how long the customer will have to pay for credit purchases before the amount is considered delinquent.

Further, maturity date for settlement of obligation is a future time. The creditor vests his trust on the debtor's ability and willingness to fulfil obligation when it falls due Alminar-Mutya (2010).

Table 4. Repayment Scheme

\begin{tabular}{lll}
\hline Statement & Mean & Interpretation \\
\hline $\begin{array}{l}\text { I am satisfied on agricultural credit in terms of its repayment } \\
\text { scheme because... }\end{array}$ & & \\
$\begin{array}{l}1 . \quad \text { it allows me to repay my loans after harvesting and } \\
\text { marketing of the crop. }\end{array}$ & 2.37 & Disagree \\
$\begin{array}{l}\text { 2. it gives grace period during the repayment scheme. } \\
\text { 3. it provides the borrowers opportunity to reschedule the }\end{array}$ & 2.28 & Disagree \\
repayment scheme. & & Disagree \\
$\begin{array}{l}\text { 4. it has no fixed or minimum repayment requirements. } \\
\text { 5. the management informs the borrowers on the interest rate that } \\
\text { maybe occurred if they repay the loan at different schedule. }\end{array}$ & 2.53 & Disagree \\
\hline Composite Mean & & Agree \\
\hline
\end{tabular}

The satisfaction of crop farmers on agricultural credit in terms of repayment scheme has a composite mean of 2.35, verbally interpreted as dissatisfied. This result shows that the respondents are not satisfied with the repayment scheme provided by the formal source of funds.

In the study Asor et al. (2009) stated that the advantage of dealing with formal funds sources such as commercial banks and government financial institutions is that bank normally provides technical and advisory services that should be of help to the borrowers if used and followed to the fullest. 
Table 5. Summary Table of Composite Mean

\begin{tabular}{lll}
\hline Satisfaction of the Respondent in terms of... & Composite Mean & Hidden VI \\
\hline Documents/ Requirements & 2.29 & Dissatisfied \\
Penalties and Charges & 2.31 & Dissatisfied \\
Interest Rate & 1.87 & Dissatisfied \\
Credit terms and condition & 2.11 & Dissatisfied \\
Repayment Scheme & 2.35 & Agree \\
\hline Grand Composite Mean & $\mathbf{2 . 1 9}$ & Dissatisfied \\
\hline
\end{tabular}

According to David (2007), small farmers continue to find it difficult to access formal credit and financing despite government efforts to increase the flow of credit to the rural sector. Only a small portion of the lending portfolio of commercial banks goes to agriculture and the bulk of these funds usually go to large farm owners and commercial farms. The inherently risky nature of agriculture, arising from climatic shocks, diseases and infestations, means that small farmers are generally considered by banks and formal financial institutions to be non-creditworthy.

\section{Difference on the Respondents' Satisfaction on Agricultural Credit when they are Grouped According to Profile}

The table presents the difference on the respondents' satisfaction when they grouped according to profile.

Table 3. Difference Between the Assessment of the Respondents when Grouped According to their Profile

\begin{tabular}{lllll}
\hline Variables & Computed Value & Tabular Value & Decision $\mathbf{H}_{\mathbf{0}}$ & Interpretation \\
\hline Crops Planted & 15.24 & 3.00 & Reject & Significant \\
Land Area & 0.62 & 3.00 & Do not reject & Not Significant \\
Frequency of Availment & 0.16 & 2.60 & Do not reject & Not Significant \\
\hline
\end{tabular}

It can be observed from the table that when the respondents were grouped according to their crops planted, the computed value of 15.24 exceeds the tabular value of 3.00 and resulted to the rejected decision and a significant difference. This shows that there is a significant difference between the satisfactions of the respondents on agricultural credit when they were grouped according to their crops planted. It indicates that crops planted can affect their satisfaction in availing agricultural credit. Farmers plant crops differently, so it is possible that they will avail loan depending on the kind or amount of crops they are going to plant. It also depends upon the necessities or condition of the area. The more they are needed, the more crops that are going to produced. Thus, the greater the amount of loans they will owe.

On the other hand, the difference between the satisfactions of crop farmers when the respondents were grouped according to their land area is not significant because the computed value is 0.62 which is less than the tabular value of 3.00. It showed that the satisfaction of the respondents on agricultural credit is not affected by their land area. This implies that land area does not affect the satisfaction of crop farmers in agricultural credit. This is probably because that they only planted similar crops such as vegetables or they may be able to plant crops but not to the entire hectares.

Likewise, when the respondents were grouped according to their frequency of availment, there is no significant difference with their satisfaction because the computed value of 0.16 is less than to its tabular value of 2.60 . It indicates that the lower the duration of availing loan, the lower their satisfaction. Another reason is that they do not borrow because they do not need it or they have enough funds for their agricultural purposes.

Thus, it can be concluded that there is a significant difference between the assessments of the respondents' satisfaction on agricultural credit when they grouped according to their crops planted. However, there exists no significant difference between the assessment of the respondents' satisfaction on agricultural credit when they grouped according to their land area and frequency of availment because their computed value of 0.62 and 0.16 did not exceed their tabular value of 3.00 and 2.60 respectively. This implies that the land area and frequency of availment of crop farmers do not affect their satisfaction on agricultural credit. 


\section{Implications of the Findings to Rural Credit Facilitation}

This study that focused on the satisfaction of crop farmers on agricultural credit revealed that numerous requirements needed for loan approval, long process for approval and accessibility to credit has contributed a lot to the pressing condition of the farmers in the research area.

In this light, credit facilitation in formal sources did not confirm the expectations of the farmers in Malvar. It means that credit restrictions such as commodity specific credit programs, credit that requires collateral, and lengthy and complicated procedures restricted the farmer from being satisfied on the formal lenders credit facilitation.

Farmers' preferences and conveniences were not well served which could lead them to take alternatives like borrowing capital in informal lenders and friends. This is an alarming situation because recovering from loans is hard to achieve due to higher interest rates. This situation contradicts to the calling of AFMA. Government passed this legislation so that farmers will refrain from obtaining capital to informal lenders.

Therefore, it implies that satisfaction on rural credit facilitation by small farmers in Malvar could be attained by providing advanced financing schemes that address the difficulties of the farmers who do not have collateral, and lessen extensive processing of documents and other requirements.

Moreover, fund allocation by the government in agriculture may be reviewed. Government budget must be properly allocated and used for the agriculture activities to help them from availing loans to informal lenders. The low dependence on informal lenders means prevention of higher interest rates which in turn can increase the farmers' productivity and profits.

\section{Conclusions and Recommendations}

This study revealed that majority of the farmers used to plant rice with a land area of $0.5-1.0$ hectare that avail agricultural credit 2 to 3 times a year. On the other hand, the level of satisfaction of crop farmers on agricultural credit with respect to documents/requirement, penalties and charges, interest rates, credit terms and conditions and repayment scheme are dissatisfied having the composite mean of 2.29, 2.31, 1.87, 2.11 and 2.31 respectively. While, difference on the respondents' satisfaction on agricultural credit when they are grouped according to crops planted is significant while land area and frequency of availment are not.

In the light of the findings and conclusions, the following recommendations are hereby given: Since small farmers in rural areas are underprivileged, the formal sources of credit like banks are encouraged to review their policy on the number of documents required for loan application, the amount of late payment fee to be incurred, interest rates, and rescheduling the repayment scheme.

Second, Central Bank of the Philippines may assigna person/officer to closely monitor and superviserural financial institutionsif they are following the rules and regulations in granting credit to small farmers in the rural areas.Third, a Need-Assessment may be conducted by the Local Government Unit of Malvar in coordination with Batangas State University, to determine the needs of the farmers, thus giving them necessary information on how they will create sound credit and financing program/policy. Also, the Local Government Unit of Malvar is encouraged to strengthen the production support programs, particularly those which provide subsidies to farmers for seeds, fertilizers and other inputs.

Batangas State University JPLPC-Malvar, specifically the College of Accountancy Business Economics and International Hospitality Management faculty members may conduct an extension program like seminar/workshop on how to properly manage resources and the value of financial discipline in achieving progress. Lastly, a follow up or similar study may be conducted considering other factors.

\section{References}

Abelido, N. O. (2006). Availment of Credit Assistance Program for Agrarian ReformBeneficiariesin Northern Samar. Unpublished Thesis: University of EasternPhilippines, University Town, Northern Samar.

Albert, J. R. (2013). Agriworkers among lowest paid - NSO. The Philippine Star. Manila Philippines.

Alminar-Mutya, R. F. (2007). Introduction to Philippine Money, Credit, and Banking (Second Edition). Metro Manila: National Book Store.

Armstrong, G., et al. (2003). (6th edition). Marketing: An Introduction. Philippines: Pearson Educational Inc.

Asor, W. (2009). Entrepreneurship in the Philippine Setting.Manila: Rex Book Store.

Besley, S. (2012). Principle of Finance. South Western Cengage Learning.

David, C. (2007). Agriculture in A. Balisacan and H. Hill (Eds.). The PhilippineEconomy: Development, Policies, 
and Challenges. Ateneo de Manila University Press. Quezon City.

David, C., \& Inocencio, A. (2007). Key Indicators for Public Expenditure in Agriculture, Natural Resources and the Environment. Manila. Philippine Institute for Development Studies (PDIS), Discussion Paper Series No. 2000-2006.

Llanto, G. (2005). Rural Finance in the Philippines Agricultural Credit Policy Council and Philippine Institute for development Studies. Makati, Philippines.

Senate of the Philippines. (2009). Policy Brief Senate Economic Planning Office (SEPO).

Tulagan, et al. (2013). Self-sufficiency Performance of the Municipality of Malvar: Unpublished Thesis. Batangas State University JPLPC Campus.

\section{Copyrights}

Copyright for this article is retained by the author(s), with first publication rights granted to the journal.

This is an open-access article distributed under the terms and conditions of the Creative Commons Attribution license (http://creativecommons.org/licenses/by/4.0/). 